\title{
Benign Prostate Phyllodes Tumor
}

National Cancer Institute

\section{Source}

National Cancer Institute. Benign Prostate Phyllodes Tumor. NCI Thesaurus. Code C5532.

A rare benign neoplasm that arises from the prostate gland and is characterized by the presence of hyperplastic glands and stroma that contains spindle-shaped cells. 